\title{
A REVIEW OF INFORMATION SYSTEMS PROGRAMS IN \\ UNIVERSITIES IN VICTORIA
}

\section{Carol Pollard}

\author{
Appalachian State University \\ Boone, North Carolina, USA \\ pollardce@appstate.edu
}

\section{Elsie S. K. Chan}

\author{
Australian Catholic University \\ Victoria, Australia \\ elsie.chan@acu.edu.au
}

\begin{abstract}
This paper outlines the current situation of Information Systems (IS) programs within the State of Victoria, Australia. It reports on how Victorian Universities are addressing the challenges associated with reducing local and international student demand, and hence enrolments, at a time when IS in particular and ICT in general are seen by the business sector as necessary components contributing to organisational success. Transcripts of interviews with 14 academicians at nine universities throughout Victoria are analysed to give a current profile of IS programs and identify the trends in their development over time. First, a profile of the State of Victoria, its education system and its ICT industry is provided to place this work in context. Next, the interview sample is described and a number of relevant topics of interest are identified and discussed, comparing and contrasting the various programs. Finally, a summary of the findings is provided in light of the framework used to guide all of the studies of the Australian IS programs described in this special issue.
\end{abstract}

Keywords: IS programs, higher education, IS enrolments, IS research

\section{INTRODUCTION}

Tertiary education in computing in Australia originated in the 'Institute of Technology' sector and only moved into the more "traditional" universities following the major changes to the Australian university system initiated by Labour’s Minister for Education John Dawkins in 1987. In turn, this led to the 'traditional' universities beginning to offer degrees and post-graduate qualifications in Information Systems (IS), originally referred to as electronic data processing (EDP) and business computing (Tatnall, 1993). Information Systems is a fascinating and pervasive discipline that has 
struggled over the past three decades to establish itself as a distinct scientific discipline. This has proved somewhat difficult and elusive possibly in part due to the fact that IS is not confined to only business activities it also profoundly affects our social activities (see, for example, Buckingham et al., 1987; DeSouza et al., 2006; Lee, 2001; Lo, 1989; Fielden, 1990; Ang, 1992; Ang and Lo, 1991; Avison, 1993; ACM, AIS and AITP, 1997; Clarke, 1999; Tatnall, 1999).

...the information systems field examines more than just the technological system, or just the social system, or even the two side by side; in addition, it investigates the phenomena that emerge when the two interact. (Lee 2001, iii-vii)

In a recent communication from Sid Huff, Chair of IS at University of Auckland, to an international listserv, he referenced a recent IT Governance Institute report that reported on the high importance of IS to the business value of organisations.

This paper reports on a study within a larger study of IS in Australia that reports on the evolution of IS teaching and research programs throughout Australia. First, a profile of the State of Victoria, its education system and its ICT industry is provided to put the work in context. Next, the interview sample is described and a number of relevant topics of interest are discussed comparing and contrasting the various programs. Finally, a summary of the findings is provided in light of the framework used to guide all of the studies of the Australian IS programs described in this special issue.

\section{Demographics of Victoria}

The state of Victoria is located in the south-eastern corner of the mainland of Australia. It is the smallest mainland state in area, representing only 3\% of the Australian land mass, but it is the most densely populated and urbanised state. Victoria began as a farming community in the 1800s. In June 2005, Victoria's population reached an estimated 5,022,300 - making it the second most populous Australian state, after New South Wales (Wikipedia, The Free Encyclopedia, 2006).

Currently, nearly $90 \%$ of Victoria's residents live in cities and towns. Melbourne is Victoria's capital and largest city, with more than $70 \%$ of all Victorians living there. The sprawling Melbourne metropolitan area is home to an estimated 3.6 million people. Other important Victorian urban centres include Geelong, Ballarat, Bendigo, Shepparton, Warrnambool and the Latrobe Valley.

\section{Education in Victoria}

Currently, Victoria has nine public universities (Table 1). The oldest, the University of Melbourne, enrolled its first student in 1855. The largest, Monash University, has an enrolment of nearly 56,000 students - more than any other Australian university in 2004. Two of Victoria's Universities (University of Melbourne and Monash University) are members of the Group of Eight (the Go8 represents Australia's leading universities), The total number of students enrolled in Victorian universities was 241,755 in 2004, an increase of $2 \%$ over the previous year. International students make up 30\% of all enrolments. The largest number of enrolments were recorded in the fields of business, administration and economics, with nearly a third of all students, followed by arts, humanities, and social science, with $20 \%$ of enrolments (Australian Bureau of Statistics, Department of Education and Training (Victoria), Department of Education, Science and Training (Commonwealth), National Centre for Vocational Education Research cited in Wikipedia, The Free Encyclopedia). 
Students may obtain the Victorian Certificate of Education on completion of secondary school education. They receive a tertiary entrance ranking, or ENTER score, to determine university admittance. From 2005, higher education providers are funded under the Commonwealth Grant Scheme (CGS) to deliver a specified number of Commonwealth supported places each year. Table 1 shows the agreed number of fully funded places, the minimum number of undergraduate places and the CGS payment to each higher education provider in 2005.

\begin{tabular}{|c|c|c|c|c|c|}
\hline $\begin{array}{l}\text { Name of University } \\
\text { Website }\end{array}$ & & Abbreviation & $\begin{array}{l}\text { Student } \\
\text { Places }^{1} \\
\text { (2005) }\end{array}$ & $\begin{array}{l}\text { Under } \\
\text { grads }{ }^{2} \\
(2005)\end{array}$ & $\begin{array}{l}\text { CGS } \\
\text { Payment }^{3} \\
\text { \$ million }\end{array}$ \\
\hline $\begin{array}{l}\text { Australian Catholic } \\
\text { www.acu.edu.au }\end{array}$ & University $^{4}$ & ACU National & 6,671 & 6,183 & 47.7 \\
\hline $\begin{array}{l}\text { Deakin University } \\
\text { www.deakin.edu.au }\end{array}$ & & Deakin & 13,963 & 13,606 & 97.2 \\
\hline $\begin{array}{l}\text { La Trobe University } \\
\text { www.latrobe.edu.au }\end{array}$ & & La Trobe & 14,375 & 13,552 & 103.3 \\
\hline $\begin{array}{l}\text { Monash University } \\
\text { www.monash.edu.au }\end{array}$ & & Monash & 21,780 & 20,469 & 160.7 \\
\hline $\begin{array}{l}\text { Royal Melbourne Institute of } \\
\text { www.rmit.edu.au }\end{array}$ & Technology & RMIT & 13,396 & 12,977 & 109 \\
\hline $\begin{array}{l}\text { Swinburne University of } \\
\text { www.swinburne.edu.au }\end{array}$ & Technology & Swinburne & 5,322 & 5,309 & 39.4 \\
\hline $\begin{array}{l}\text { The University of } \\
\text { www.unimelb.edu.au }\end{array}$ & Melbourne & Melbourne & 18,595 & 17,285 & 150.9 \\
\hline $\begin{array}{l}\text { University of Ballarat } \\
\text { www.ballarat.edu.au }\end{array}$ & & $\begin{array}{l}\text { University of } \\
\text { Ballarat }\end{array}$ & 3,305 & 3,210 & 261.6 \\
\hline $\begin{array}{l}\text { Victoria University } \\
\text { www.vu.edu.au }\end{array}$ & & $\begin{array}{l}\text { Victoria } \\
\text { University }\end{array}$ & 9,537 & 8,807 & 62.6 \\
\hline
\end{tabular}

Table 1 - Australian Government fully funded places and CGS payment by university in Victoria, $2005^{5}$

\section{Sophisticated ICT Industry in Victoria}

Victoria is home to a vibrant and sophisticated Information and Communication Technology (ICT) industry which boasts a strong component of locally grown companies. Australian-owned firms account for approximately 69\% of the industry in Victoria. It is a centre for research and development which is leading the Australian (and often global) research and development programs across a broad range of industry sectors.

In 2001-02, Victoria’s globally focused ICT industry had a turnover of AUD\$19.8 billion (US \$15.3 billion) and a skilled and creative workforce of 60,000. With export revenue of AUD\$615 million (US \$476.4 million) and R\&D expenditure of AUD\$303 million (US \$235 million), the ICT

\footnotetext{
${ }^{1}$ A Commonwealth supported place is one equivalent full time student load (EFTSL).

${ }^{2}$ Total Commonwealth supported places excludes Research Training Scheme places.

${ }^{3}$ CGS payments include enabling loading, regional loading, and medical student loading.

${ }^{4}$ ACU figures in Table 1 are for ACU multi-state campuses, not only Victoria.

${ }^{5}$ Source: Commonwealth of Australia 2005, pp. 45-46
} 
industry is at the heart of the modern Victorian economy. Although Victoria accounts for less than $25 \%$ of Australia's population, it is home to $31 \%$ of all Australian ICT jobs. These comprise $48 \%$ of all jobs in hardware manufacturing, $41 \%$ of jobs in software engineering and $35 \%$ of all ICT consulting jobs (Government of Victoria, 2005). Leading Israeli IT services and solutions provider Ness Technologies, Inc. will open their Australia New Zealand headquarters in Melbourne creating up to 50 new jobs, announced by the Minister for Information and Communication Technology, Marsha Thomson in April 2006 (Government of Victoria, 2006).

High internet usage rates and world-class infrastructure make Victoria a test-bed for e-commerce companies and, as a result, Victoria has emerged as Australia's leader in business-to-business and business-to-consumer e-commerce. Recently, it was reported that Melbourne in particular has a critical mass of creativity and skills to develop a competitive ICT hotspot (Newcomersnetwork.com, 2006). These statistics provide a natural conduit for a discussion of the evolution of the many strong ICT programs that exist within Victoria universities.

\section{RESEARCH METHOD}

Walsham (1993; 1995) recommends case studies for interpretivist research, although this is by no means the only way in which case studies can be used, as clarified by Yin (2003). A case study is used to explore or describe a particular issue within a specified unit of study (Benbasat et al. 1987; Shanks et al. 1993; Miles \& Huberman 1994 and Yin 1994). Hence a qualitative, interpretivist approach was chosen to conduct the research upon which this paper is based. Within and between case analysis was performed to offer a rich description and comparison of IS programs at the nine universities represented, as indicated in Table 1.

Face-to-face interviews were conducted with 14 senior academics in 2005. The number of interviews conducted at each university ranged from one to three, depending on availability of participants and included one key person from each university as the primary source of data. The semi-structured face-to-face interviews were primarily based upon the standardised interview protocol developed for use in the larger IS-in-Australia study. At the outset of each meeting, the researcher opened the session with a set of standard introductory remarks designed to (1) indicate the importance and purpose of the interview, (2) give assurance of anonymity and confidentiality to the participant and (3) establish rapport. Each interview began with elicitation of demographic information (name, title, department) and then seeking information on the following topics of interest:

- Relative Size and Administrative Placement of the IS Presence at their University

- The Extent to Which IS at the University is Impacted by Local Contingencies

- The Extent to Which IS is Identified as a Separate Field at their University

- Distinctive Features of the IS Curriculum at their University

- Distinctive Features of IS Research at their University

- The Key People Who Have Impacted IS in Universities in Victoria

Throughout the interview, spontaneity and tangential discussion were invited, to encourage participants to reveal possibly useful anecdotal data. Mintzberg (1979) advocated the use of this technique and described its importance:

For while systematic data create the foundation for our theories, it is the anecdotal data that enable us to do the building. Theory building seems to require rich description, the richness that comes from anecdote. We uncover all kinds of relationships in our 
hard data, but it is only through the use of this soft data that we are able to explain them. (p. 583)

With agreements from the interviewees, most interviews were tape recorded in their entirety to minimise possible interviewer bias. Upon transcription, interviewees were provided with a copy of their transcript and asked to provide feedback; revisions were made by the researchers as necessary. Available documentation and archival material was also collected and analysed to provide some triangulation of data (Denzin and Lincoln, 1998).

\section{Information Systems Programs in Universities in Victoria}

Data was collected at nine universities across Victoria, on the topics listed above Based on an analysis of the interview transcripts and the available documentary evidence, each of these areas is explored in detail in the following sections.

\section{Relative Size and Administrative Placement of the IS Presence}

The total number of IS tertiary students in Victoria is approximately 7,000. A comparison of the size of the IS presence ranges from 76 students at Australian Catholic University (Melbourne campus) to approximately 1,000 at University of Ballarat and Monash as shown in Table 2. Full time IS academic staff number from 3 to 50. However, it was noted by those interviewed at Monash that their faculty size had been culled significantly since 2004 due to falling student numbers over the past several years. And, in a message from Rodney Turner to AISWorld LISTSERV ISWorld, dated May 16 2006, it was announced that Victoria University was reducing its IS staff from 26 to 14 (53.8\%) as a beginning measure in staff reduction.

\begin{tabular}{|c|c|c|c|c|}
\hline $\begin{array}{l}\text { Name of } \\
\text { University }\end{array}$ & Faculty & $\begin{array}{l}\text { Department, School } \\
\text { or Group }\end{array}$ & $\begin{array}{l}\text { IS } \\
\text { academic } \\
\text { staff in } \\
2005\end{array}$ & $\begin{array}{l}\text { No. of IS } \\
\text { students } \\
\text { in } 2005\end{array}$ \\
\hline $\begin{array}{l}\text { ACU } \\
\text { National }\end{array}$ & Arts and Sciences & $\begin{array}{l}\text { Business and } \\
\text { Informatics }\end{array}$ & 3 & 76 \\
\hline Deakin & $\begin{array}{l}\text { Business and Law } \\
\text { Science and Technology }\end{array}$ & $\begin{array}{l}\text { Information } \\
\text { Systems; } \\
\text { Information } \\
\text { Technology }\end{array}$ & $\begin{array}{l}30 \\
38\end{array}$ & $\begin{array}{c}150 \\
3155\end{array}$ \\
\hline La Trobe & $\begin{array}{l}\text { Science, Technology and } \\
\text { Engineering }\end{array}$ & $\begin{array}{l}\text { Computer Science } \\
\text { and Computer } \\
\text { Engineering }\end{array}$ & 16 & 252 \\
\hline Monash & Information Technology & $\begin{array}{l}\text { Berwick, Caulfield, } \\
\text { Clayton, Gippsland }\end{array}$ & 150 & 1000 \\
\hline RMIT & $\begin{array}{l}\text { Science, Engineering and } \\
\text { Technology }\end{array}$ & $\begin{array}{l}\text { Business } \\
\text { Information } \\
\text { Technology; } \\
\text { Computer Science } \\
\text { and Information } \\
\text { Technology }\end{array}$ & $\begin{array}{l}41 \\
51\end{array}$ & 622 \\
\hline
\end{tabular}




\begin{tabular}{|c|c|c|c|c|}
\hline Swinburne & $\begin{array}{l}\text { Information } \\
\text { Communication } \\
\text { Technologies }\end{array}$ & $\begin{array}{l}\text { Astrophysics \& } \\
\text { Supercomputing; } \\
\text { Computer Science \& } \\
\text { Software } \\
\text { Engineering; } \\
\text { Information } \\
\text { Systems; } \\
\text { Telecommunications }\end{array}$ & 52 & 500 \\
\hline Melbourne & $\begin{array}{l}\text { Science } \\
\text { Engineering }\end{array}$ & $\begin{array}{l}\text { Information } \\
\text { Systems; } \\
\text { Software } \\
\text { Engineering }\end{array}$ & 45 & 400 \\
\hline $\begin{array}{l}\text { University of } \\
\text { Ballarat }\end{array}$ & N.A. & $\begin{array}{l}\text { Information } \\
\text { Technology } \\
\text { Mathematical } \\
\text { Sciences }\end{array}$ & 54 & 1,010 \\
\hline $\begin{array}{l}\text { Victoria } \\
\text { University }\end{array}$ & $\begin{array}{l}\text { Business and Law } \\
\text { Health, Engineering and } \\
\text { Science }\end{array}$ & $\begin{array}{l}\text { Information } \\
\text { Systems; } \\
\text { Computer Science } \\
\text { and Mathematics }\end{array}$ & $\begin{array}{l}26 \\
35\end{array}$ & 800 \\
\hline
\end{tabular}

Table 2 - IS Presence in Universities in Victoria

Table 2 shows that while all nine universities in Victoria represented in the study offer IS programs, their location within the university structure differ by institution. As a whole, IS programs in universities in Victoria can be categorised between Business and Science $\backslash$ Technical $\backslash$ Engineering faculties. Six universities have departments located within faculties of Science \Technical \ Engineering, whereas Deakin, RMIT and Victoria University offer Information Technology programs both through the Business and Science $\backslash$ Technical $\backslash$ Engineering faculties.

\section{The Extent to Which IS Has a Separate Identity within the University}

The data revealed a trend in an overwhelming majority of universities in Victoria to recognise Information Systems as a separate entity (Table 3). In universities where this was the case, this separate identity was expressed as "a clear demarcation between IS subjects and others in the faculty” (RMIT, Victoria University), "a strong reputation in industry” (Swinburne) and "IS has long had a strong separate identity" (Monash). A specific example is that for many years in the 1970s and 1980s, Caulfield and the Chisholm Institute of Technology (subsequently merged into Monash) pioneered IS education in Victoria. An early activity was the "Programmer in Training" (PIT) scheme of the Commonwealth Government. The issue of "competing” with business, information technology and computer science departments was also raised by some in connection with the existence of a separate identity. Overall, the existence of a separate identity for IS was viewed positively, although at Melbourne it was indicated while IS has a separate identity as a department, "not many people know about our department". Of the two universities (University of Ballarat and La Trobe) that do not afford IS a separate identity, La Trobe has experienced some problems with this status, including the lack of representation of IS journals and conferences in a recent journal and conference ranking exercise undertaken to improve the department's (Computer 
Science and Computer Engineering) research profile. At University of Ballarat, IS does not have separate administrative status and IS lecturers teach into other areas of the School of IT and Mathematical Science. This is also true for ACU National, as one of the three IS lecturers teaches the Business units and IS does not have separate administrative status.

Despite the generally positive perception of having a separate identity, those senior academics interviewed were relatively evenly divided between "same" and "less" in their views on Status as shown in Table 3. Only one senior academic at Monash felt that IS academics were viewed more highly than their colleagues in other departments. At the four universities in Victoria where it was perceived that IS academics saw themselves as having a lesser status than their colleagues a number of reasons were given. In some cases it appeared to be due to the relatively new and evolving nature of IS departments in Australia (Melbourne, RMIT, Victoria University) and one of the respondents at Swinburne felt that the perception of IS faculty was that they are "less prominent in research than their colleagues". At those universities where the perception was that there was no difference between the status of IS academics and their colleagues no elaboration for this perception was forthcoming.

Interestingly, Table 3 shows that status and separate identity are not necessarily correlated. For example, academics at University of Ballarat considered their status "no more or less" and those at La Trobe were said to have mixed perceptions of status. In contrast, at those universities that had a separate identity, many viewed themselves as having less status for the reasons described above.

\begin{tabular}{lll} 
University & Separate ID & Status \\
& & \\
\hline ACU National & No & Same \\
Deakin & Yes & Same \\
La Trobe & No & Same/Less \\
Monash & Yes & Same/Higher \\
RMIT & Yes & Less \\
Swinburne & Yes & Less \\
Melbourne & Yes & Less \\
University of Ballarat & No & Same \\
Victoria University & Yes & Less
\end{tabular}

Table 3 - IS Identity and Status in Universities in Victoria

\section{The Extent to Which IS Is Impacted by Local Contingencies}

While it appears that universities in Victoria are seeking increased collaboration with the local community and industry as part of their strategic vision, as in the strong industry-based learning degree programs at Swinburne and Monash Universities, established around 1990 as an initiative of the Business Council of Australia, the majority of universities felt the influence of local industries was negligible in terms of impacting their curriculum. However, efforts to increase interaction with external partners are currently underway and, in some cases, are being promoted by top university officials. In the case of Victoria University it is the Vice Chancellor who is spearheading these initiatives. Victoria University was one of the earliest universities to link the program to systems in the market. The Faculty of Business and Law and SAP signed an agreement in March 1998 to enable the University to develop courses and conduct research based around SAP's Enterprise Resource Planning System referred to as SAP R/3. In the case of Monash, the Dean of IS and full 
professors were primarily instrumental in this area. At Swinburne the Faculty as a whole were attempting to increase ties to industry to “(be) alert to any possible 'competitive advantage' in responding to special local needs". Where local influences were present, the most influential industries named were manufacturing and consulting services. At ACU National, IS curricula are not affected by local factors but in fact more by the ethical influence in the Catholic mission as well as ethical and social responsibilities which will influence the curricula to a certain extent.

National influences, on the other hand, are affecting IS curriculum across Victoria. For example, Monash appears to be impacted more strongly by national rather than local community and industry influences, or by individual influences within the University attributed to staffing changes over the years. Likewise, Swinburne saw national influences as being most influential.

The cyclic nature of demand for IS courses was seen, in most cases, to be the factor that influenced IS enrolment most. Some respondents emphasised it was not always factors "local" to their Australian location that affected their IS curriculum. For example, RMIT's IS program was impacted by factors at their offshore Hong Kong location. This is not surprising since many of the universities indicated that international students accounted for a large percentage of their enrolments at both graduate and postgraduate levels.

\section{Distinctive Features of the IS Curriculum}

Universities in Victoria offer a wide range of undergraduate and postgraduate IS course and programs. Table 4 summarises the programs offered at the various institutions.

The greatest majority of the nine institutions represented offer the standard suite of BIS and BIS (Hons), Graduate Certificate, Graduate Diploma and Masters level programs. Within Victoria, all universities offer PhD level IS programs although not all universities currently had PhD students enrolled.

IS/IT programs offered at undergraduate level and masters by course work in universities in Victoria are listed in Appendix 1.

\begin{tabular}{|c|c|c|c|c|c|c|c|c|c|}
\hline University & BIS & $\begin{array}{c}\text { BIS } \\
\text { (Hons) }\end{array}$ & BIT & BBIS & MIS & $\begin{array}{c}\text { MBI } \\
\text { S }\end{array}$ & MIT & MIM & $\mathrm{PhD}$ \\
\hline ACU National & $\mathrm{X}$ & $\mathrm{X}$ & & & & & & & $\mathrm{X}$ \\
\hline Deakin & $\mathrm{X}$ & $X$ & $\mathrm{X}$ & $\mathrm{X}$ & $\mathrm{X}$ & & $\mathrm{X}$ & & $X$ \\
\hline La Trobe & $\mathrm{X}$ & $X$ & $X$ & & & & $X$ & & $X$ \\
\hline Monash & $\mathrm{X}$ & $\mathrm{X}$ & $\mathrm{X}$ & & $\mathrm{X}$ & $\mathrm{X}$ & $\mathrm{X}$ & $\mathrm{X}$ & $X$ \\
\hline RMIT & & & & & & & & & $\mathrm{X}$ \\
\hline Swinburne & $\mathrm{X}$ & $\mathrm{X}$ & $\mathrm{X}$ & & $\mathrm{X}$ & & $\mathrm{X}$ & & $X$ \\
\hline University of Ballarat & $\mathrm{X}$ & $\mathrm{X}$ & & & & $\mathrm{X}$ & $\mathrm{X}$ & & $\mathrm{X}$ \\
\hline Melbourne & $\mathrm{X}$ & $X$ & & & $\mathrm{X}$ & & $\mathrm{X}$ & & $X$ \\
\hline Victoria University & $\mathrm{X}$ & & & $\mathrm{X}$ & $\mathrm{X}$ & & & & $\mathrm{X}$ \\
\hline
\end{tabular}

Legend:

$\begin{array}{ll}\text { BIS } & \text { Bachelor of Information Systems } \\ \text { BIS(Hons) } & \text { Bachelor of Information Systems with Honours } \\ \text { BIT } & \text { Bachelor of Information Technology } \\ \text { BBIS } & \text { Bachelor of Business Information Systems }\end{array}$




$\begin{array}{ll}\text { MIS } & \text { Master of Information Systems } \\ \text { MBIS } & \text { Master of Business Information Systems } \\ \text { MIM } & \text { Master of Information Management and Systems } \\ \text { PhD } & \text { Doctor of Philosophy }\end{array}$

Table 4 - Diversity of IS Programs Offered

In addition to the traditional Bachelor of Information Systems or Information Technology, Bachelor of Business Information Systems and the Masters of Information Systems, a few institutions offer cross-disciplinary courses. Examples of these cross-disciplinary course are shown below.

\begin{tabular}{ll}
\multicolumn{1}{c}{ University } & \multicolumn{1}{c}{ Courses } \\
\hline ACU & IS and Business (Accounting, Marketing or Human Resource Management) \\
LaTrobe & Bachelor of Computing with Applied Science \\
& Bachelor of Computing with Visual Arts \\
Victoria University & $\begin{array}{l}\text { Joint degrees with Arts and Science and Engineering faculties } \\
\text { Masters in Enterprise Resource Planning } \\
\text { Marketing/E-Commerce }\end{array}$
\end{tabular}

Table 5 - Examples of Cross-Disciplinary Courses in Universities in Victoria

It is observed that in 2002 ACU National students tended to study a single degree, Bachelor of Information Systems. Starting from 2004, students preferred to study a double degree. The reason for this change may be due to the perceptions of graduates, who believe graduates with double degrees could find jobs more easily than those with a single degree. Many of the universities have a large population of international students the majority of whom are from Asia, with only a small representation from Europe. Offshore IS programs are offered on campuses located in Hong Kong, Thailand, Singapore, China, and Malaysia. Generally speaking, the courses taught are less technical than would be found in a department of computer science or information technology.

The distinctive themes taught within many of these programs varied considerably as shown below.

\begin{tabular}{ll}
\multicolumn{1}{c}{ University } & \multicolumn{1}{c}{ Distinctive Theme } \\
\hline Deakin & Electronic Commerce \\
LaTrobe & Educational Theory and Practice \\
Monash & Decision Analysis and Information Management \\
RMIT & Security, Decision Support, Usability, Interface Design \\
Swinburne & Design and Support of Business Processes \\
Univerity of Ballarat & Global Information Systems \\
Victoria University & ERP
\end{tabular}

Table 6 - Distinctive Themes at Universities in Victoria

It is also interesting to observe that universities offer many IS/IT related masters programs nowadays compared to a decade ago. As mentioned in Keen (1996 pp.129-132) there were only three universities offering IS/IT related masters programs by course work. They were Master of Information Systems at Monash, Master of Business (IT) at RMIT and Master of Business in Computing at Victoria University of Technology (now renamed as Victoria University). 


\section{IS Research Programs in Universities in Victoria}

Turning from the teaching profile and diversity of programs to that of research, an interesting picture emerges. Table 7 demonstrates the diversity of research streams underway in universities in Victoria and recognises two successful formal research centres. Those universities who have active $\mathrm{PhD}$ programs have been successful in varying degrees in attracting and maintaining $\mathrm{PhD}$ students to support, in part, their research programs.

Overall, despite the large number of diverse topics being studied, IS research output in universities in Victoria was seen as being lower than in other departments. It should be noted, however that for the most part IS research output appears to have been increasing over the past 3-5 years. Efforts are underway to bolster research output. Comments indicative of this include one at Monash to the effect that "All IS academics will be expected to be 'research active' by 2008” and at University Ballarat, where it is a current requirement that "all academics in the school are expected to undertake research".

The mode of IS research in universities in Victoria is predominantly interpretive. Only University Ballarat reported using “multi-method, with an emphasis on quantitative techniques”.

\begin{tabular}{|c|c|c|c|}
\hline University & Areas of Research & Formal Research Groups & $\begin{array}{l}\text { No. of } \\
\text { PhD } \\
\text { students }\end{array}$ \\
\hline CU National & $\begin{array}{l}\text { IS Education } \\
\text { E-Commerce Education }\end{array}$ & & 1 \\
\hline Deakin & $\begin{array}{l}\text { Requirement Engineering } \\
\text { IT Security } \\
\text { Knowledge Management } \\
\text { Supply Chain Management } \\
\text { Software Engineering } \\
\text { E-Commerce }\end{array}$ & $\begin{array}{l}\text { Supply Chain Management } \\
\text { (SCM) and Business-to- } \\
\text { business (B2B) eCommerce }\end{array}$ & 20 \\
\hline a Trobe & $\begin{array}{l}\text { Computational Intelligence } \\
\text { IS Education } \\
\text { Equity Issues of Women in IT } \\
\text { IT Adoption and Impact }\end{array}$ & & 2 \\
\hline Monash & $\begin{array}{l}\text { Knowledge Management } \\
\text { Systems Development } \\
\text { Decision Support Systems } \\
\text { Information Management } \\
\text { IT Management } \\
\text { E-Business } \\
\text { Conceptual Modelling }\end{array}$ & $\begin{array}{l}\text { Centre for Decision Support } \\
\text { and Business Intelligence } \\
\text { Research }\end{array}$ & 60 \\
\hline RIT & $\begin{array}{l}\text { Strategic IS } \\
\text { E-Learning } \\
\text { E-Commerce }\end{array}$ & $\begin{array}{l}\text { Knowledge Management } \\
\text { E-Business }\end{array}$ & 30 \\
\hline
\end{tabular}




\begin{tabular}{|c|c|c|}
\hline Swinburne & $\begin{array}{l}\text { IS Governance } \\
\text { Process Modelling } \\
\text { IS Project Management } \\
\text { Health Informatics }\end{array}$ & $\begin{array}{l}\text { Centre for Information } \\
\text { Technology Research }\end{array}$ \\
\hline Melbourne & $\begin{array}{l}\text { E-Commerce } \\
\text { Technology Adoption } \\
\text { Usability Design } \\
\text { Security }\end{array}$ & Knowledge Discovery \\
\hline $\begin{array}{l}\text { University of } \\
\text { Ballarat }\end{array}$ & $\begin{array}{l}\text { IT Education } \\
\text { Data Mining and Informatics } \\
\text { Mathematics and Statistical } \\
\text { Analysis } \\
\text { Distributed Simulation }\end{array}$ & $\begin{array}{l}\text { Centre for Informatics and } \\
\text { Optimisation (CIAO) }\end{array}$ \\
\hline $\begin{array}{l}\text { Victoria } \\
\text { University }\end{array}$ & $\begin{array}{l}\text { Semantics Webs } \\
\text { Business Process Modeling } \\
\text { Negotiation Support } \\
\text { Legal Systems in IS } \\
\text { Ethics, Privacy and Censorship } \\
\text { Portals for Medical and Aged } \\
\text { Care Support } \\
\text { ERP }\end{array}$ & $\begin{array}{l}\text { Electronic } \\
\text { Research }\end{array}$ \\
\hline
\end{tabular}

Table 7 - Research Streams in-Universities in Victoria

\begin{abstract}
Although research is considered a high priority at almost all universities in Victoria, available funding appears to have a negative correlation with the avowed importance of researching. Perceptions of "very little funding”, "dwindling funding” and "having trouble attracting ARC and other external funding" were evident in the data. Where funding has been obtained, it is primarily in the form of competitive grants from University internal sources or associated with established Research Centres, with some funding forthcoming from industry. A relatively few IS departments have been successful in securing external grants from granting agencies such as ARC. However, there appears to be a trend towards encouraging external grants rather than relying on internal funding, which in almost all cases was seen to be increasingly difficult to secure.
\end{abstract}

Respondents stressed that rewards, when available, are increasingly being awarded for research that results in journal publications rather than conference papers.

\title{
Victoria Government support for IS programs
}

The Victorian government is aware the number of students in IS has dropped. In order to encourage more students to take IS courses in the universities, in 2005 Multimedia Victoria initiated a project, the Industry \& Universities Collaboration Pilot Program, which provides funds to universities in Victoria to promote and improve IS courses. All universities in Victoria will benefit from this program 
The Hon. Marsha Thomson, Minister for Information, Communication and Technology in the Victorian State Government convened a meeting on 26 May 2006 to discuss matters relating to an apparent shortage of ICT skills in Australia, and notably in Victoria.

\section{Key People Who Have Impacted IS in Universities in Victoria}

A number of key individuals were recognised for their contributions to IS in Victorian Universities. Predominantly, these individuals were long-standing academic leaders.

Examples included Tony Adams at RMIT, who was named as the champion for the establishment and direction of the IS department, along with Marianne Broadbent, Head of the former IM School in Arts who worked with Prof. Adams to establish the RMIT IS research and coursework frameworks. Robert Johnson was identified as an influential force at Melbourne as was Gerald Murphy at Swinburne and Angela Scollary for her tireless work to establish the IS school at Victoria. The respondent from University of Ballarat recognised Prof. Sid Morris, their Head of School as one who "has had a huge amount to do with the success we are having" and acknowledged the important contributions of Prof. Wayne Robinson, University of Ballarat's Deputy Vice-Chancellor (Academic and Research), together with that of Prof. Alex Rubinov, Director of CIAO.

A long list of influential individuals was forthcoming from respondents at Monash. These included Gerry Maynard for his leadership in establishing the IS department, Jack Greig, current Head of IS and the person responsible for the introduction of Systems Analysis units, Phil Steele, David Arnott, Graeme Shanks, Frada Burstein, Julie Fisher, Ron Weber and Ian Martin, an academic involved in Industry-Based Learning at the Clayton campus

Less frequently mentioned, but no less important, are those non-academics who were seen to have influenced course design and skill requirements, such as the representatives at Bendigo Bank who have been supportive and influential at La Trobe.

\section{SUMMARY}

Despite declining enrolments and dwindling research support, from a teaching perspective IS programs in the universities in Victoria appear to be well placed to provide top calibre IS graduates at the undergraduate and postgraduate levels to meet the projected increased demand from industry and IS programs projected over the next 5 years. Programs at all tertiary education levels are varied and carefully crafted, influenced by national rather than local impacts.

It is encouraging to see that the research output and quality of the IS community in Victoria have improved greatly over the last few years. A large number of IS academics have gained PhDs, published in leading IS journals, joined editorial boards of prestigious journals and some have obtained ARC Linkage and Discovery grants. While research topics are diverse within the state, methods are not. IS academics in Victoria appear to align themselves more closely with interpretivist European research traditions than with the quantitative, positivist approach more commonly found in North America. Despite the increased importance that research appears to have in measuring performance, funding is dwindling and success in securing external competitive grants such as those offered by the Australian Research Council appears to continue to elude the majority of IS researchers in Victoria. 
In relating the Victoria data to the underlying framework that guides the IS in Australia study as proposed by Whitley (1984), it would appear that the Victoria data do not fully support IS as a distinct scientific discipline. Each of Whitley's criteria will be addressed separately in light of the Victoria data to demonstrate the conclusion reached.

The first of Whitley's three conditions that must be met in order for an area of study to be considered a "distinct scientific field" is a social process that results in scientific reputations becoming socially prestigious and control critical rewards. Mingers and Stowell (1997) suggest this can be evidenced through publications and success in attracting research funding. Clearly, Victoria researchers view themselves as being somewhat less "respected" than their counterparts in other disciplines with only one respondent feeling that IS researchers were of higher status than those in other departments. On the other hand, documentary evidence shows that a number of senior IS academics in Victoria have attained status as Full Professors and are recognised as being as qualified as their peers in other more mature disciplines. The deficiency in meeting this criterion is perhaps more telling in regard to "attracting research funding" where the data clearly demonstrate that external funding support for IS research continues to be elusive and IS researchers appear to be losing ground as they struggle with dwindling internal funding.

The second of Whitley's criteria is the need to establish standards of research competence and skills. Here, the Victoria data add to the long-standing discussion on whether IS is a discipline (Dickson, Benbasat and King 1982; Benbasat and Weber 1996; Boudreau, et al. 2001) and the current perception that IS continues to align itself more closely with a "fragmented adhocracy" as suggested by Checkland and Howell (1998) and Kanungo (2004) than a distinct discipline. For example, while there were pockets of successful grant applications and a limited number of Research Centres throughout the state, the data revealed an overall lack of success in attracting research funding which could be construed as a negative reflection on research competence and skills that appear to be limited to interpretivism and lacking in the application of the more diverse, blended approach usually evident in more mature disciplines.

The third and final criterion is one that requires the existence of a unique symbol system to allow exclusion of outsiders and unambiguous communication between initiates within the field. Only $50 \%$ of Victoria IS programs are recognized as a separate entity and the research topics under scrutiny would clearly demonstrate a heavy reliance on reference disciplines with little or no discussion of the use of an IS theory. This would suggest that this criterion has not been met.

In conclusion, IS programs in Victoria appear to be evolving to meet the demands of industry from a teaching perspective, but somewhat lacking in the area of research output vis-à-vis their counterparts in other departments. However, while some universities have yet to establish IS as a separate entity, research output is increasing along with efforts to successfully win external competitive grants. It would appear that the main challenges being faced include the significant drop in students studying IS and the expected drop in full-fee overseas students, coupled with the Commonwealth Government's new Research Quality Framework (RQF), which will focus attention on the quality of IS research. Opportunities include building on recent successes in IS research in Victoria that should lead to a stronger IS research base in the future. 


\section{ACKNOWLEDGEMENTS}

The authors would like to express their gratitude to Angela Scollary for her valuable contribution to the data collection phase of this research project and to Graeme Shanks for his insightful comments on an earlier draft of this paper. Carol Pollard was affiliated with the School of Information Systems, University of Tasmania, Australia when this research began.

\section{REFERENCES}

ACM, AIS and AITP (1997) IS'97 Model Curriculum and Guidelines for Undergraduate Degree Programs in Information Systems. http://webfoot.csom.umn.edu/faculty/gdavis/curcomre.pdf accessed 30 May 2006.

Ang, A.Y. (1992) "Australian Information Systems Curricula: A Comparison between the Views of Universities and TAFE Colleges", Proceedings of Third Australian Conference on Information Systems, Wollongong, Australia, 5-8 October, 747-758.

Ang, A.Y. \& Lo, B.W.N. (1991) "Changing Emphasis in Information Systems Curricula: an Australian Industrial Perception”, Proceedings ACC'91 MOSAIC, Adelaide, 6-10 October, 11-28.

Avison, D.E. (1993) "Research in Information Systems Development and the Discipline of Information Systems”, Proceedings of 4th Australasian Conference on Information Systems, Queensland, Australia, 28-30 September, 1-27.

Benbasat, I., Goldstein, D.K., \& Mead, M. (1987) “The Case Research Strategy in Studies of Information Systems”, MIS Quarterly, Vol 3, pp 368-386.

Benbasat, I. \& Weber, R. (1996) "Research Commentary: Rethinking 'Diversity' in Information Systems Research”, Information Systems Research, Vol 7 No 4, pp 389-399.

Boudreau, M., Gefen, D., \& Straub, D. (2001) “Validation in Information Systems Research”, MIS Quarterly, Vol 25 No 1, pp 1-16.

Buckingham, R.A., Hirschheim, R.A., Land F.F. \& Tully,C.J. (1987) "Information Systems Curriculum: a Basis for Course Design”, In Buckingham et. Al. (ed.) Information Systems Education: Recommendations and Implementation, University Press, Cambridge, Great Britain, pp 114-133.

Checkland, P., \& Holwell, S. (1998) Information, Systems and Information Systems - Making Sense of the Field. University of Illinois Press, Urbana, Illinois.

Clarke, R. (1999) “Comments on Information Systems Curriculum”. http://www.anu.edu.au/people/Roger.Clarke/SOS/ISCurric.html accessed 30 May 2006.

Commonwealth of Australia (2005) Higher Education Report 2004-05, http://www.dest.gov.au/NR/rdonlyres/136CDC4E-9770-464D-BDCF-

72E56B031C6A/8092/highered_report_fullversion11.pdf accessed 30 May 2006.

Denzin, N.K. \& Lincoln, Y.S. (1998) The Landscape of Qualitative Research, Sage Publishing, Thousand Oaks, CA. 
DeSouza, K.C., El Sawy, O.A., Galliers, R.D., Loebbecke, C. \& Watson, R. (2006) “Beyond Rigor and Relevance Towards Responsibility and Reverberation: Information Systems Research That Really Matters”, Communications of the AIS, Vol 17, pp 341-353.

Dickson, G.W., Benbasat, I. \& King, W.R. (1982) “The MIS area: Problems, Challenges and Opportunities”, DataBase, Vol 14 No 1, pp 7-12.

Fielden, K. (1990) "Facts, Skills and Creativity: An Innovative Approach to Learning in Information Systems”, Proceedings of First Annual Conference on Information Systems, Monash University, Melbourne, Australia, 6 February, 2-14.

Government of Victoria (2006) "Melbourne home to new headquarters for leading Israeli IT company 27 April”. http://invest.vic.gov.au/News/News/ness+technologies.htm accessed 30 May 2006.

Kanungo, S. (2004) “On the Emancipatory Role of Rural Information Systems”, Information and People, Vol 17 No 4, pp 407-422.

Keen, C. (1996) “A Survey of Course Work Masters in Information Systems in Australia”. In D. Arnott, K. Dampney and A. Scollary (Eds.), The Australian Debate on Information Systems Curriculum, Proceedings of the Australian In formation Systems Curriculum Working Conference, 24-25, Sep. Monash University, Australia, 119-132.

Lee, A. (2001) “Editor’s Comments”, MIS Quarterly Vol 25 No 1, pp iii-vii.

Lo, B.W.N. (1989) “A Survey of Information Systems Educational Programmes in Australian Tertiary Institutions, Working Paper Series No. 1”, Department of Information Systems, The University of Wollongong.

Miles, M.B. and Huberman, A.M. (1994) Qualitative Data Analysis, SAGE Publications, London.

Mingers, J. \& Stowell, F. (Eds.) (1997) Information Systems: An Emerging Discipline? Maidenhead, Berkshire, UK: McGraw-Hill.

Mintzberg, H. (1979) “An Emerging Strategy of “Direct” Research”, Administration Science Quarterly, Vol 24, pp 580-589.

Newcomersnetwork.com (2006) "Business in Melbourne, Victoria, Australia - facts, figures, information, statistics, industries, manufacturing, biotechnology, ICT, innovation and more” http://www.newcomersnetwork.com/mel/oursay/expertadvice/bimv.php accessed 30 May 2006.

Ridley, G. (2006) “Characterising Information Systems in Australia: A Theoretical Framework”, Australasian Journal of Information Systems, Vol 13 No 3, pp. 38-60.

Shanks, G., Rouse, A. and Arnott, D. (1993) 'A Review of Approaches to Research and Scholarship in Information Systems’, Working Paper 3/93, School of Information Management and Systems, Monash University, Melbourne, Australia.

Tatnall, A. (1993) "A Curriculum History of Business Computing in Victorian Tertiary Institutions from 1960-1985”, Masters thesis, Deakin University, Geelong.

Tatnall, A. (1999) "Innovation and Change in the Information Systems Curriculum of an Australian University: a Socio-Technical Perspectives”, $\mathrm{PhD}$ thesis, Central Queensland University.

Walsham, G. (1993) Interpreting Information Systems in Organization, Wiley, Chichester. 
Walsham, G. (1995) “Interpretive Case Studies in IS Research: Nature and Method”, European Journal of Information Systems, Vol 4, pp 74-81.

Whitley, R. (1984) The Intellectual and Social Organization of the Sciences, Clarendon Press, Oxford, UK.

Wikipedia, The Free Encyclopedia (2006) "Victoria (Australia)". http://en.wikipedia.org/wiki/Victoria_(Australia) accessed 30 May 2006.

Yin R. K. (1994) Case Study Research, Design and Methods, Sage Publications, Beverly Hills, California, US.

Yin, R. K. (2003) Case Study Research: Design and Methods, $3^{\text {rd }}$ Edition. Sage Publishing, Thousand Oaks, CA.

\section{THE AUTHORS}

Carol Pollard is Associate Professor of Information Systems. Her research interests include decision support systems, impact of emerging technologies and technology transfer. Her current research focuses on the healthcare sector and small to medium-sized firms. Carol has published her research in MIS Quarterly, Journal of Management Information Systems and Information and Management and has presented at numerous national and international conferences. Carol is currently Research Director, Center for Applied Research on Emerging Technologies (CARET) at Appalachian State University; Vice President, International of GITMA; Chair, ACIS Executive Committee and an Advisory Board member of Teradata University Network.

Elsie Chan currently plays a dual role in Australian Catholic University. She is a lecturer in Information Systems as well as the Course Coordinator of Business Programs in School of Business and Informatics, Melbourne campus. She obtained her MSc degree in Artificial Intelligence at University of Essex, United Kingdom in the late 1980's. Since then she has been lecturing in various universities in Hong Kong, China and Macau before she migrated to Australia. She obtained her $\mathrm{PhD}$ at Deakin University, Melbourne. Her research areas are electronic commerce / electronic business and information systems

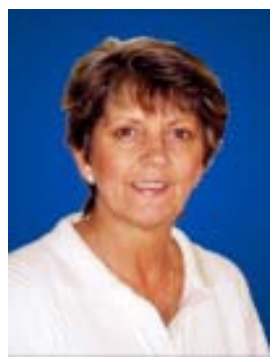
education, marketing and web development

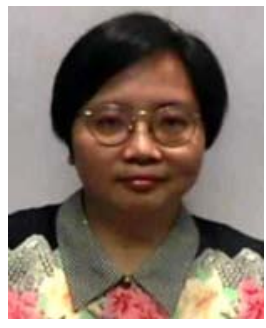




\section{APPENDIX 1}

Undergraduate and Masters by Coursework Programs in Information Systems and Information Technology offered by universities in Victoria

Australian Catholic University (Melbourne Campus)

Bachelor of Information Systems

Bachelor of Information Systems (Hons)

Bachelor of Business / Bachelor of Information Systems

Deakin University

Bachelor of Information Technology (IT Security)

Bachelor of Information Systems/Bachelor of Information Technology

Bachelor of Information Systems

Bachelor of Information Systems (Hons)

Bachelor of Engineering/Bachelor of Information Technology

Bachelor of Information Technology (Multimedia Technology)

Bachelor of Information Technology (Computer Science and Software Development)

Bachelor of Information Technology (Games Design and Development)

Bachelor of Information Technology (Web and Mobile Technologies)

Master of Arts (Professional Communication)/Master of Information Technology

Master of Information Technology

Master of Information Technology (Professional)

Master of Information Technology/Master of Commerce

Master of Information Technology/Master of Information Systems

Master of Accounting Information Systems

Master of Commerce/Master of Information Systems

La Trobe University

Bachelor of Information Technology (Computer Networks)

Bachelor of Information Technology (Information Systems)

Bachelor of Information Technology (Software Development)

Bachelor of Information Systems/Bachelor of Business

Master of Information Technology (Computer Networks)

Master of Information Technology (Intelligent Systems \& Internet Computing)

Monash

Bachelor of Business Information Systems

Bachelor of Information Technology and Systems

Bachelor of Arts / Bachelor of Information Management and Systems

Bachelor of Commerce / Bachelor of Business Information Systems

Master of Applied Information Technology

Master of Business Administration/Master of Information Management and Systems 
Master of Information Management and Systems

Master of Information Management and Systems Professional

Master of Information Systems

Master of Information Technology

Master of Information Technology (Minor Thesis)

Royal Melbourne Institute of Technology

Bachelor of Business (Business Information Systems)

Bachelor of Applied Science (Honours) (Computing and Internet Technology)

Bachelor of Applied Science (Information Technology)

Bachelor of Applied Science (Honours) (Computing and Internet Technology)

Master of Business (Business Information Technology)

Master of Applied Science (Information Security)

Master of Applied Science (Information Systems)

Master of Applied Science (Information Technology)

Master of Engineering (Information Technology)

Master of Technology (Information Technology)

Master of Technology (Internet and Web Computing)

Swinburne University

Bachelor of Information Technology (Honours)

Bachelor of Science (Information Technology)

Bachelor of Information Systems (Honours)

Bachelor of Information Technology

Bachelor of Business Information Systems / Bachelor of Business

Bachelor of Business Information Systems

Master of Information Systems Management / Master of Accounting

Master of Information Systems Management

Master of Information Systems Management /Master of Business Administration

Master of Technology (Information Technology)

Master of Information Technology

The University of Melbourne

Bachelor of Information Systems

Bachelor of Information Systems (Honours)

Master of Business and Information Technology

Master of Information Systems

Master of Information Technology

Master of Information Technology in Education

University of Ballarat

Bachelor of Information Systems

Bachelor of Information Technology 
Bachelor of Information Technology (Professional Practice)

Master of Business Information Systems

Master of Information Systems

Master of Information Technology

Master of Information Technology Studies

Master of Information Technology Studies and Master of Business Administration

Master of Information and Communication Technology

Victoria University

Bachelor of Business (Accounting/Information Systems)

Bachelor of Business (Information Systems)

Bachelor of Business (Tourism Management/Information Systems)

Bachelor of Arts/Bachelor of Business (Information Systems)

Bachelor of Business (Information Systems) (Honours)

Bachelor of Science in Information Technology

Master of Business in Information Systems

Master of Business in Information Systems and Enterprise Resource Planning Systems 
